\title{
Tomato progenies selection in Rondônia, Brazil
}

\author{
Maria José Marques ${ }^{1} \mathbb{D}$; Juliana de Fátima Vizú ${ }^{2} \mathbb{D}$; Danilo F da Silva Filho ${ }^{1} \mathbb{D}$; César Augusto Ticona- \\ Benavente ${ }^{1} \mathbb{D}$
}

${ }^{1}$ Instituto Nacional de Pesquisas da Amazônia (INPA), Manaus-AM, Brazil; marques.f.j.m@gmail.com; danilo@inpa.gov.br; cesar.benavente@ gmail.com; ${ }^{2}$ Universidade Federal de São Carlos (UFSCar), Araras-SP, Brazil; vizu.juliana@gmail.com

\begin{abstract}
This study aimed to select endogamic progenies of tomato cv. Yoshimatsu and to conduct a progeny test in the state of Rondônia. The experiment was carried out in a randomized block design with four replicates and eight plants per plot, spacing $1 \times 0.5 \mathrm{~m}$, with one stem. A significant variation was observed among the fifteen progenies for productivity (2.0-5.5 kg plant $\left.{ }^{-1}\right)$, seed mass with placenta (18-31.5 $\left.\mathrm{g} \mathrm{fruit}^{-1}\right)$, number of fruits per plant (18.8-38.7) and soluble solids (3.4-4. ${ }^{\circ}$ Brix). No significant variation was noticed for fruit size, pericarp thickness, number of locules, $\mathrm{pH}$, number of flowers and fruit set, though. P6 progeny showed to be the most productive one $\left(110 \mathrm{t} \mathrm{ha}^{-1}\right)$ : average fruit mass was $142.5 \mathrm{~g}$, salad type tomato, 7.5 locules, $3.5^{\circ}$ Brix, $\mathrm{pH} 4.2,60.9$ flowers per plant and $64.2 \%$ fruit set. Thus, these data show genetic variability of cultivar Yoshimatsu, being possible to obtain lines and/or cultivars with medium to large fruits adapted to the state of Rondônia.
\end{abstract}

Keywords: Solanum lycopersicum, progeny test, plant breeding, Amazon, agronomical performance.

\begin{abstract}
RESUMO
Seleção de progênies de tomate em Rondônia

O objetivo deste trabalho foi selecionar progênies endogâmicas de tomate, a partir da cultivar Yoshimatsu e realizar teste de progênies no estado de Rondônia, seguindo o delineamento de blocos ao acaso com quatro repetições e oito plantas por parcela, num espaçamento de $1 \times 0,5 \mathrm{~m}$, conduzidas com uma haste. Mediante analise dos resultados verificou-se que há variação significativa entre as quinze progênies para produtividade $\left(2,0-5,5 \mathrm{~kg}_{\text {planta }}^{-1}\right)$, massa das sementes com placenta $\left(18,0-31,5 \mathrm{~g}\right.$ fruto $\left.^{-1}\right)$, número de frutos planta ${ }^{-1}(18,8-38,7)$ e sólidos solúveis $\left(3,4-4,2^{\circ}\right.$ Brix $)$, porém não para tamanho de fruto, espessura do pericarpo, número de lóculos, $\mathrm{pH}$, número de flores e pegamento de frutos. A progênie P6 foi a mais produtiva $(110 \mathrm{t} /$ ha), com massa média do fruto de $142,5 \mathrm{~g}$, formato tipo salada, 7,5 lóculos, $3,5^{\circ}$ Brix, $\mathrm{pH} 4,2$, número de flores 60,9 e pegamento de frutos $64,2 \%$. Assim, há variabilidade genética dentro da cultivar Yoshimatsu e é possível obter linhagens e/ou cultivares com frutos médios a grandes adaptados ao estado de Rondônia.
\end{abstract}

Palavras- chave: Solanum lycopersicum, teste de progênies, melhoramento, Amazônia, desempenho agronômico.

\section{Received on March 20, 2018; accepted on November 16, 2018}

D eveloping tomato varieties adapted to the Amazon Region is extremely important due to the growing demand of this vegetable in the region. Tomato statistics indicate it has been continuously planted in Amazonas for the last 30 years (SIDRA, 2017), an average yield of $21.5 \mathrm{t} \mathrm{ha}^{-1}$ is still far below the national average (64.6 $\left.\mathrm{t} \mathrm{ha}^{-1}\right)$ (LSPA, 2017), though.

This low productivity is related to biotic and abiotic factors. Among biotic factors, diseases and pests should be considered, mainly bacterial wilt caused by Ralstonia solanacearum (Martins et al., 2013); among abiotic factors, high temperature and humidity, low luminous intensity and low nutrient and acid soils should be cited (Jyothi et al., 2012).

In a wide study on weather conditions, Alvares et al. (2013) used 2950 Brazilian weather stations and evaluated three prevailing climate conditions for the Brazilian Amazon: humid tropical (Af), tropical monsoon $(\mathrm{Am})$ and tropical with dry winter (Aw). The Af climate has an average altitude of $100 \mathrm{~m}$, temperature and average annual rainfall of $25^{\circ} \mathrm{C}$ and $2700 \mathrm{~mm}$, respectively. 'Af' and 'Aw' climates have altitudes from 200 to $450 \mathrm{~m}$, annual average temperatures from 26 to $24.5^{\circ} \mathrm{C}$, and annual rainfall between 2,500 and $1,500 \mathrm{~mm}$, respectively. In this same study, the authors identified the climate in each state. In Amazonas and
Acre predominates Af climate $(82.3 \%$ and $70.5 \%$ of its area, respectively); in Rondônia, Amapá, Pará, Roraima and Mato Grosso do Sul, Am climate predominates $(100 \%, 100 \%, 66.6 \%$, $55.2 \%$ and $45.6 \%$, respectively). In Mato Grosso, the dominant climate is Aw (52.8\%). This climatic difference influences the tomato production in the northern region of Brazil. In 2016, the state of Pará produced 6,600 $\mathrm{t}$ in 254 ha and Rondônia 4,600 t in 180 ha, being the most productive states in the Amazon region (LSPA, 2017), in contrast to the state of Amazonas which produced $162 \mathrm{t}$ in 18 ha (LSPA, 2017).

The state of Rondônia is one of the main producers in the region and its 
production is used to meet the demand of the city of Manaus [2.1 million people, according to IBGE (2017)], in the state of Amazonas, especially the tomato production. Studies on the evaluation of tomato cultivars point out that hybrids dominate the market. However, these cultivars were developed for mild climate regions such as Goiás, São Paulo and Minas Gerais, without resistance to bacterial wilt, a common disease of tomato in tropical regions.

The most adapted cultivar for humid tropic (Af) is Yoshimatsu, which is a result from the crossing between $\mathrm{IH}$ 40 and UH-7976 (Noda et al., 1997), developed in Instituto Nacional de Pesquisas da Amazônia (National Research Institute of Amazon, INPA). This cultivar shows high level of resistance to bacterial wilt (polygenic inheritance) (Noda et al.,1997; Menezes, 1998). Curiously, some phenotypic variability was noticed even in $\mathrm{F}_{8}$ generation. Thus, new selections originated varieties Y-L1, Y-L2, Y-L3 (Noda et al., 2007). Another cultivar which is recommended for the Amazon is the clonal variety 'Pará Belo', since it shows resistance to $R$. solanacearum Biovar III (Cheng \& Chu, 2002).

For a continuous tomato production in Rondônia, it is necessary to make some breeding in this state. A good strategy to begin it is to make selections using the cultivar Yoshimatsu, in order to obtain either parents or cultivars. Given the above, this study aimed to select and test agronomically progenies of this variety in the state of Rondônia.

\section{MATERIAL AND METHODS}

The experiments were carried out in setor de produção vegetal de olericultura do Instituto Federal de Educação, Ciência e Tecnologia de Rondônia, campus Colorado do Oeste, at km 63 on highway BR $435\left(13^{\circ} 06^{\prime} 54^{\prime \prime}\right.$, $60^{\circ} 29^{\prime} 10^{\prime \prime}, 460 \mathrm{~m}$ altitude). The soil is classified as Eutrophic Red Ultisol, wavy-plain topography (Embrapa, 2006). According to Köppen, the climate is Am (Alvares et al., 2013).

Tomato seeds, cultivar Yoshimatsu, indeterminate growth habit, of
Germplasm Bank of Instituto Nacional de Pesquisas da Amazônia (INPA) in Manaus, AM were used. Sowing was performed in August, 2014. Seedlings were grown in 128-cell styrofoam trays, filled with commercial substrate Vivatto Slim Plus and kept in a greenhouse until transplant (30 days after sowing).

The experiment was carried out in two stages: the first was to select individual plants and the second stage to test the progenies. In the first stage, 100 seedlings were transplanted without any experimental design, spacing $1 \mathrm{x} 1$ $\mathrm{m}$; the seedlings were conducted with two stems and staked vertically using ribbons. Fertilization was performed per pit using the formulation NPK (4-30-10) and one liter of organic fertilizer in the form of cattle manure. Top dressing fertilization began 30 days after transplant (DAT), with a 15day interval between each application, using $15 \mathrm{~g}$ of formulation NPK (20-0020) per pit. From 75 to 120 DAT, 20 g of formulation NPK (15-00-30) were applied in each pit.

Right after reaching fruit maturation stage, through observations on sanity, fruit shape homogeneity and productivity, 15 plants were visually selected. The following traits were evaluated: average fruit mass (MF), number of locules (NL), fruit width (LF), fruit length (CF), pulp thickness (EP), $\mathrm{pH}$ and total soluble solids. Seeds were taken and stored forming 15 progenies. Additionally, the variability within the cultivar in a study carried out 30 days after transplant was evaluated. Twenty five plants were sampled randomly, and the following traits were evaluated: number of fruits per plant (NFP), number of flowers (NF), number of aborted flowers (NFA) and number of clusters (NC) until the maturation phase of the fruits of the first cluster. Using these data, Boxplots were built using the computer program STATISTICA 12 (Stat soft, Inc, 2014).

In the second phase, 15 progenies were prepared according to the procedures adopted in the first phase and transplanted according to randomized block design, with fifteen treatments (progenies), four blocks and eight plants per plot, spacing $1 \times 0.5 \mathrm{~m}$, conducted with one stem, and staked vertically using ribbons. Cultural practices adopted were identical to the ones performed previously. Harvest started one month after transplant, extending for three weeks. The following traits were evaluated: number of fruits per plant (NFP), number of flowers (NF), number of aborted flowers (NAF) and number of clusters (NB). A sample of five fruits per plot was considered to evaluate average mass of fruits (MF), number of locules $(\mathrm{NL})$, diameter (D) and length (L) of the fruit, length/diameter ratio (L/D), pulp thickness (PT), mass of seeds with placenta (MS), $\mathrm{pH}$ and total soluble solids ( ${ }^{\circ}$ Brix).

Precision scale, digital caliper, calibrated tabletop $\mathrm{pH}$ meter, digital bench refractometer, and crusher for particles less than $1 \mathrm{~cm}$, stainless steel spatulas and beakers, were used for laboratorial evaluations. Total soluble solids were determined based on the methodology described by Moretti et al. (1998), crushing the samples for three minutes and then a small quantity of a homogenized material was put in the refractometer, previously calibrated with distilled water, and the reading was expressed in degrees Brix. Data were submitted to analysis of variance; then, Duncan test $(\mathrm{P} \leq 0.05)$ was used to compare the averages, using ASSISTAT program version 7.7 (Silva \& Azevedo, 2016).

\section{RESULTS AND DISCUSSION}

\section{Individual plant selection}

The traits which showed higher variation were number of flowers (55-132) and fruits (17-63) per plant, followed by fruit set (22.08-61.16\%), number of aborted flowers (2-20) and number of clusters (14-26) (Figure 1). These findings show that there exists variation for fruit productivity, showing that the selection of progenies using cultivar Yoshimatsu can be promising.

According to Noda \& Machado (1992), higher abortion rate of flowers in this cultivar occurs under nursery conditions. In the field, abortion rate is lower due to the greater movement of the plant, caused by wind and by 
Table 1. Fruit physicochemical traits of 15 visually selected tomato plants from Yoshimatsu cultivar. Colorado do Oeste, IFRO, 2015.

\begin{tabular}{|c|c|c|c|c|c|}
\hline Plants & $\begin{array}{c}\text { Fruit } \\
\text { mass (g) }\end{array}$ & $\begin{array}{c}\text { Fruit length } \\
\text { (cm) }\end{array}$ & $\begin{array}{c}\text { Fruit } \\
\text { diameter } \\
(\mathrm{cm})\end{array}$ & $\begin{array}{c}\text { Length/ } \\
\text { diameter ratio }\end{array}$ & $\begin{array}{c}\text { Pericarp } \\
\text { thickness } \\
(\mathrm{cm}) \\
\end{array}$ \\
\hline $\mathrm{P} 1$ & 92.5 & 5.03 & 6.14 & 0.81 & 0.53 \\
\hline $\mathrm{P} 2$ & 86.7 & 4.91 & 5.67 & 0.86 & 0.57 \\
\hline P3 & 72.3 & 4.48 & 5.18 & 0.86 & 0.41 \\
\hline P4 & 62.8 & 4.41 & 4.84 & 0.91 & 0.47 \\
\hline P5 & 76.7 & 4.76 & 5.14 & 0.92 & 0.48 \\
\hline P6 & 99.1 & 4.80 & 5.82 & 0.82 & 0.49 \\
\hline P7 & 87.9 & 5.05 & 5.55 & 0.90 & 0.54 \\
\hline P8 & 68.9 & 4.63 & 5.06 & 0.91 & 0.42 \\
\hline P9 & 85.3 & 4.96 & 5.64 & 0.87 & 0.50 \\
\hline P10 & 68.7 & 4.52 & 5.09 & 0.88 & 0.39 \\
\hline P11 & 82.7 & 4.74 & 5.51 & 0.86 & 0.53 \\
\hline P12 & 65.4 & 4.52 & 4.84 & 0.93 & 0.53 \\
\hline P13 & 84.3 & 4.93 & 5.69 & 0.86 & 0.51 \\
\hline P14 & 97.6 & 5.06 & 6.66 & 0.75 & 0.52 \\
\hline $\mathrm{P} 15$ & 58.7 & 4.32 & 4.84 & 0.89 & 0.48 \\
\hline Average & 79.31 & 4.74 & 5.44 & 0.87 & 0.49 \\
\hline \multirow[t]{2}{*}{ CV (\%) } & 12.73 & 0.25 & 0.52 & 0.05 & 0.05 \\
\hline & $\begin{array}{c}\text { Number of } \\
\text { locules }\end{array}$ & \multicolumn{2}{|c|}{$\begin{array}{c}\text { Seed mass with } \\
\text { placenta (g) }\end{array}$} & ${ }^{\circ}$ Brix & pH \\
\hline $\mathrm{P} 1$ & 5.8 & \multicolumn{2}{|c|}{17.06} & 4.06 & 4.45 \\
\hline $\mathrm{P} 2$ & 5.5 & \multicolumn{2}{|c|}{17.52} & 4.05 & 4.20 \\
\hline P3 & 5.2 & \multicolumn{2}{|c|}{13.94} & 3.91 & 3.56 \\
\hline P4 & 4.0 & \multicolumn{2}{|c|}{11.25} & 4.15 & 4.14 \\
\hline P5 & 4.3 & \multicolumn{2}{|c|}{15.75} & 4.10 & 4.37 \\
\hline P6 & 6.9 & \multicolumn{2}{|c|}{19.62} & 4.64 & 4.70 \\
\hline P7 & 4.7 & \multicolumn{2}{|c|}{17.05} & 4.15 & 4.06 \\
\hline P8 & 5.4 & \multicolumn{2}{|c|}{12.92} & 3.87 & 4.11 \\
\hline P9 & 5.6 & \multicolumn{2}{|c|}{17.69} & 4.03 & 4.29 \\
\hline P10 & 4.7 & \multicolumn{2}{|c|}{15.37} & 4.15 & 4.05 \\
\hline P11 & 4.7 & \multicolumn{2}{|c|}{15.87} & 4.06 & 3.78 \\
\hline P12 & 3.6 & \multicolumn{2}{|c|}{16.58} & 3.80 & 3.83 \\
\hline P13 & 5.1 & \multicolumn{2}{|c|}{16.12} & 4.11 & 3.48 \\
\hline P14 & 5.9 & \multicolumn{2}{|c|}{19.80} & 4.17 & 4.20 \\
\hline P15 & 4.9 & \multicolumn{2}{|c|}{9.46} & 4.03 & 4.00 \\
\hline Average & 5.09 & \multicolumn{2}{|c|}{15.73} & 4.09 & 4.08 \\
\hline CV (\%) & 0.82 & \multicolumn{2}{|c|}{2.85} & 0.19 & 0.32 \\
\hline
\end{tabular}

greater number of insect pollinators. In relation to number of fruits per plant, productivity superior to the one found in the previous experiment, with the same cultivar in Manaus, producing 25 fruits per plant was noticed (Pena et al., 2010). This greater productivity in Rondônia showed that cv. Yoshimatsu is able to obtain higher yields under 'Am' climate, such as in Rondônia, Amapá, Pará,
Roraima and Mato Grosso (Alvares et al., 2013) than in humid tropic (Af climate). As a consequence it is possible to conclude that in Acre this cultivar could have a similar performance to the obtained in Manaus, since $75.5 \%$ of its area is Af climate.

Morphoagronomic and physicochemical analyzes of the fruits of the 15 plants selected in this study (Table
1) are mainly characterized by their average fruit mass (58.7-99.1 g). These values were superior to the ones found by Sousa et al. (2011) who, among other accessions, also evaluated cultivar Yoshimatsu in the state of Roraima, where the averages did not exceed $34.69 \mathrm{~g}$. This could be explained because these authors conducted the experiment in pots, which would limit plant development.

Physico-chemical traits help to evaluate fruit quality. Regarding fruit's $\mathrm{pH}$, findings showed an average of 3.5-4.7. According to Guilherme et al. (2008) and Rodrigues et al. (2008), 4.5 is the $\mathrm{pH}$ range for the highest consumer acceptability. Fruits with values lower than 3.7 show high acidity, being less appreciated by consumers (Borguini \& Silva, 2007). Following this criterion just P1 (4.45) and P6 (4.70) would have greater acceptability. However, $\mathrm{pH}$ ranges superior to 4.5 promote microorganism proliferation (Monteiro et al., 2008). Considering this information, only the plant $\mathrm{P} 1$ would be the most suitable for the market.

Soluble solid content is related to flavor and to industrial yield for pulp, and it is influenced by fertilization, temperature and irrigation (Monteiro et al., 2008). In the selected plants, this trait ranged from 3.80 to 4.64 . In cultivars, a variation of this content has been ranging according to cultural practices: conventional or organic; for instance, for cv. Carmen values of 4.7 and $4.2^{\circ}$ Brix, respectively, were found, and cv. Débora, $4.9^{\circ}$ Brix in both cultivations (Borghini, 2002). Plant P6 can be recommended as the most promising one since it showed the highest value for this trait (Table 1).

In relation to fruit characteristics, fruit shape of selected plants is only salad type, since length is lower than diameter and ratio $C / D$ ranged from 0.75 (P15) to 0.91 (P4 and P8). The number of locules ranged from 3.6 to 6.9. Plants with higher number of locules also have greater size and consequently higher mass of $65.4 \mathrm{~g}$. These results corroborate previous studies which state that there is a direct relationship between number of locules and fruit size (Lippman \& Tanksley, 2001; Barrero \& Tanksley, 
2004). In relation to pericarp thickness (Table 1), a range from 0.39 to 0.57 was verified. Plants showing thickness superior to 0.5 were P1, P2, P7, P11, P12 and P13. Considering that pulp content is related to pericarp thickness (Ferreira et al., 2004), plants showing thickness superior to $0.5 \mathrm{~cm}$ would be considered the most promising.

\section{Progeny test}

Considering the evaluated traits, only productivity, fruit mass, seed mass with placenta, ${ }^{\circ}$ Brix and number of fruits per plant (Table 2) showed no significant variance. This indicates there to be genetic variability in cv. Yoshimatsu, for important productivity components and chemical composition of fruits.

The most productive progeny was P6 with $111 \mathrm{t} \mathrm{ha}^{-1}\left(5.53 \mathrm{~kg} \mathrm{plant} \mathrm{t}^{-1}\right)$, spacing $1 \times 0.5 \mathrm{~m}$. Considering the common spacing used to produce fresh tomato, 1x1 m, P6 productivity would be at least $66 \mathrm{t} \mathrm{ha}^{-1}$, value close to the national average (67.8 $\mathrm{t} \mathrm{ha}^{-1}$ ) (LSPA, 2017). On the other hand, previous tests using cv. Yoshimatsu in spacing $1 \mathrm{x} 1$ showed productivity ranging from 18.84 to $38.40 \mathrm{t} \mathrm{ha}^{-1}$ (Noda, 2007; Pena et al., 2010). Thus, P6 progeny raised

Table 2. Physicochemical and agronomical traits of selected tomato progenies from cv. Yoshimatsu. Colorado do Oeste, IFRO, 2015.

\begin{tabular}{|c|c|c|c|c|c|c|c|}
\hline Progenies & $\begin{array}{l}\text { Productivity } \\
\text { (t/ha) }\end{array}$ & $\begin{array}{l}\text { Fruit mass } \\
\text { (g) }\end{array}$ & $\begin{array}{l}\text { Length } \\
\text { (cm) }\end{array}$ & $\begin{array}{l}\text { Diameter } \\
\quad(\mathrm{cm})\end{array}$ & $\begin{array}{l}\text { Ratio length/ } \\
\text { diameter }\end{array}$ & $\begin{array}{c}\text { Pericarp } \\
\text { thickness }(\mathbf{c m})\end{array}$ & $\begin{array}{c}\text { Number of } \\
\text { locules }\end{array}$ \\
\hline $\mathrm{P} 1$ & $77.57 \mathrm{~b}$ & $142.05 \mathrm{ab}$ & 5.49 & 6.32 & 0.86 & 0.54 & 5.75 \\
\hline $\mathrm{P} 2$ & $72.64 \mathrm{~b}$ & $127.64 \mathrm{ab}$ & 4.82 & 6.39 & 0.81 & 0.51 & 6.50 \\
\hline P3 & $69.69 \mathrm{bc}$ & $131.60 \mathrm{ab}$ & 5.04 & 6.04 & 0.83 & 0.51 & 6.25 \\
\hline P4 & $62.60 \mathrm{bc}$ & $116.05 \mathrm{~cd}$ & 5.17 & 5.53 & 0.86 & 0.51 & 6.00 \\
\hline P5 & $61.70 \mathrm{bc}$ & $125.77 \mathrm{ab}$ & 4.71 & 5.98 & 0.82 & 0.49 & 6.50 \\
\hline P6 & $110.60 \mathrm{a}$ & $142.49 \mathrm{ab}$ & 5.10 & 6.09 & 0.84 & 0.55 & 7.50 \\
\hline P7 & $40.88 \mathrm{f}$ & $108.51 \mathrm{~cd}$ & 5.11 & 5.66 & 0.90 & 0.58 & 5.00 \\
\hline P8 & 42.04 ef & $90.84 \mathrm{f}$ & 4.85 & 5.77 & 0.84 & 0.53 & 5.00 \\
\hline P9 & $50.64 \mathrm{~cd}$ & $108.66 \mathrm{~cd}$ & 4.95 & 5.86 & 0.84 & 0.49 & 5.25 \\
\hline P10 & $61.59 \mathrm{bc}$ & $90.94 \mathrm{f}$ & 4.82 & 5.63 & 0.85 & 0.46 & 5.25 \\
\hline P11 & 60.12 bc & $116.60 \mathrm{~cd}$ & 4.90 & 5.84 & 0.83 & 0.47 & 5.25 \\
\hline P12 & $57.55 \mathrm{bc}$ & $120.29 b c$ & 5.00 & 5.89 & 0.85 & 0.53 & 5.25 \\
\hline P13 & $45.20 \mathrm{de}$ & $102.92 \mathrm{de}$ & 5.09 & 6.03 & 0.84 & 0.53 & 5.75 \\
\hline P14 & $64.27 \mathrm{bc}$ & $148.77 \mathrm{a}$ & 5.16 & 6.60 & 0.78 & 0.51 & 6.75 \\
\hline $\mathrm{P} 15$ & $41.64 \mathrm{ef}$ & $98.14 \mathrm{ef}$ & 5.02 & 5.80 & 0.86 & 0.48 & 5.50 \\
\hline Average & 79.799 & 134.03 & 4.79 & 5.65 & 0.84 & 0.50 & 6.50 \\
\hline \multirow[t]{2}{*}{ CV (\%) } & 21.05 & 12.26 & 7.64 & 8.07 & 5.80 & 9.62 & 24.02 \\
\hline & $\begin{array}{c}\text { Seed mass with } \\
\text { placenta }(\mathrm{g})\end{array}$ & ${ }^{\circ}$ Brix & $\mathbf{p H}$ & $\begin{array}{c}\text { Number of } \\
\text { flowers }\end{array}$ & $\begin{array}{l}\text { Number of } \\
\text { fruits }\end{array}$ & $\begin{array}{l}\text { Fruit set } \\
(\%)\end{array}$ & $\begin{array}{c}\text { Number of } \\
\text { clusters }\end{array}$ \\
\hline $\mathrm{P} 1$ & $25.32 \mathrm{bc}$ & $3.65 \mathrm{bc}$ & 4.08 & 51.37 & $27.50 \mathrm{bc}$ & 54.28 & 7 \\
\hline $\mathrm{P} 2$ & $25.93 \mathrm{~b}$ & $3.77 \mathrm{ab}$ & 4.12 & 49.62 & $28.83 \mathrm{bc}$ & 60.38 & 7 \\
\hline P3 & $22.10 \mathrm{bc}$ & $3.82 \mathrm{ab}$ & 4.23 & 47.75 & $26.33 \mathrm{bc}$ & 56.64 & 7 \\
\hline P4 & $21.99 \mathrm{bc}$ & $3.95 \mathrm{ab}$ & 4.37 & 46.00 & $26.87 \mathrm{bc}$ & 58.61 & 7 \\
\hline P5 & $23.26 \mathrm{bc}$ & $3.95 \mathrm{ab}$ & 4.20 & 44.62 & $24.75 \mathrm{~cd}$ & 55.35 & 6 \\
\hline P6 & $26.25 \mathrm{~b}$ & $3.45 \mathrm{c}$ & 4.18 & 60.87 & $38.66 \mathrm{a}$ & 64.22 & 7 \\
\hline P7 & $17.99 \mathrm{~d}$ & $3.65 \mathrm{bc}$ & 4.14 & 40.62 & $18.83 \mathrm{~d}$ & 49.34 & 6 \\
\hline P8 & $21.50 \mathrm{bc}$ & $3.58 \mathrm{bc}$ & 3.88 & 36.62 & $23.62 \mathrm{~cd}$ & 67.74 & 7 \\
\hline P9 & $19.89 \mathrm{~cd}$ & $3.42 \mathrm{c}$ & 4.12 & 49.50 & $23.50 \mathrm{~cd}$ & 48.23 & 6 \\
\hline P10 & $20.64 \mathrm{bc}$ & $3.97 \mathrm{ab}$ & 4.25 & 55.62 & $34.00 \mathrm{ab}$ & 62.04 & 7 \\
\hline P11 & $22.01 \mathrm{bc}$ & $3.60 \mathrm{bc}$ & 4.44 & 47.37 & $25.66 \mathrm{~cd}$ & 55.74 & 7 \\
\hline P12 & $20.34 \mathrm{bc}$ & $3.92 \mathrm{ab}$ & 4.29 & 47.37 & $23.87 \mathrm{~cd}$ & 50.20 & 6 \\
\hline P13 & $21.92 \mathrm{bc}$ & $3.70 \mathrm{bc}$ & 4.19 & 35.50 & $21.62 \mathrm{~cd}$ & 60.83 & 6 \\
\hline P14 & $31.46 \mathrm{a}$ & $3.45 \mathrm{c}$ & 4.15 & 47.00 & $22.12 \mathrm{~cd}$ & 47.15 & 7 \\
\hline $\mathrm{P} 15$ & $19.83 \mathrm{~cd}$ & $4.17 \mathrm{a}$ & 4.26 & 41.50 & $21.25 \mathrm{~cd}$ & 52.22 & 6 \\
\hline Average & 23.82 & 3.80 & 4.07 & 47.00 & 29.00 & 58.73 & 6.5 \\
\hline CV (\%) & 15.49 & 7.54 & 4.75 & 22.14 & 19.24 & 16.59 & 9.07 \\
\hline
\end{tabular}


productivity in approximately $100 \%$. This fact shows this cultivar, even though having been selected for the humid tropics (Af), to be responsive to environmental improvement (Am), also with gains from selection. Considering the above given data, one may conclude cv. Yoshimatsu is able to be used as base population so as to start a tomato breeding program in the state of Rondônia.

For average fruit mass and seed mass with placenta, P14 progeny showed the highest values for both traits: 148.77 $\mathrm{g}$ and $31.46 \mathrm{~g}$, respectively. Followed by P6 progenies (142.5 g; $26.3 \mathrm{~g}), \mathrm{P} 1$ (142.1 g; $25.3 \mathrm{~g}$ ) and P3 (131.6 g; 22.1 g). Cv. Yoshimatsu has average fruit mass between 16 and $45 \mathrm{~g}$ (Pena et al., 2010; Sousa et al., 2011; Andrade et al., 2013). The results show that from cv. Yoshimatsu varieties with average fruit mass similar to hybrids 'Débora' and 'Fascínio', whose masses range from 150 to $200 \mathrm{~g}$, could be obtained.

For Monteiro et al. (2008), the highest Brix of tomato fruits increase commercial quality. Based on this state, the progenies which most stood out were P15 (4.17), P10 (3.97), P4 and P5 (both 3.95) and P12 (3.92), which are above $3.90^{\circ}$ Brix found by Andrade et al. (2013) for cv. Yoshimatsu in Manaus. Since progenies showed a significant difference among themselves we concluded there to be genetic variability for this trait; which failed to reach up to 4.9 as shown by cv. Débora (Borghini, 2002). Taiz \& Zeiger (2004) have reported that in addition to plant genetics and management, luminous intensity also increases the leaves photosynthetic activity, allowing the plant itself to accumulate a larger amount of sugars in their fruits, regardless the used treatment. Thus, these progenies could have their ${ }^{\circ}$ Brix increased if they were planted in July and August in Rondônia, as at this time there is less rainfall and consequently more light.

For number of fruits per plant, a significant difference among progenies (standing out progeny P6 with 38.7 ) was noticed (Table 2). This value was superior to 25.98 found by Pena et al. (2010) studying the same cultivar on dry land in the municipality of Manaus. This fact shows that plant selection in Rondônia was efficient. This trait is directly related to fruit set percentage (total number of fruits/total number of flowers x 100), which did not show any significant difference among progenies. This could be explained since there is a great variation of number of flowers per plant in a plot, raising the average square of fruit set percentage and, consequently the significant limit difference used

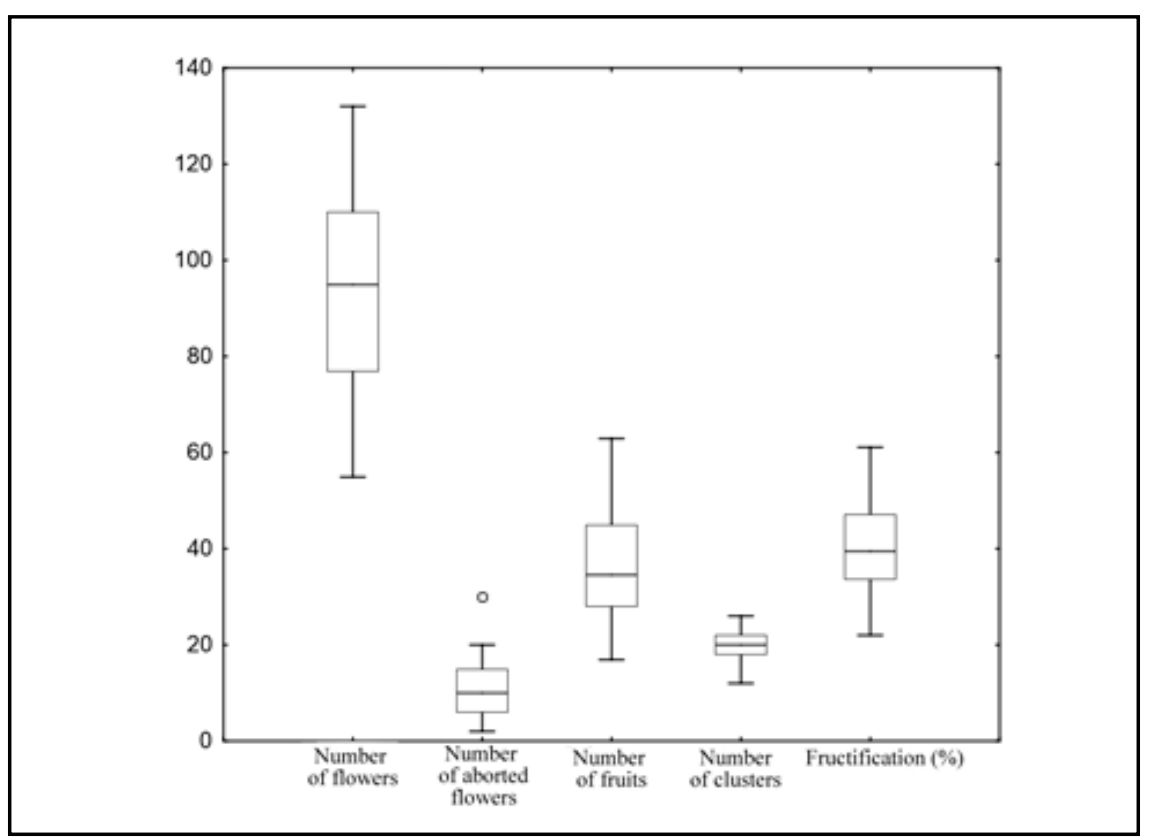

Figure 1. Boxplot of traits related to flowers and fruits of 25 tomato plants, cv. Yoshimatsu. Colorado do Oeste, IFRO, 2015. to compare the averages. Fruit set is related to number of aborted flowers. According to Villareal et al. (1977), high temperatures promote abortion due to stylet length exceeding anther size. This does not happen in cv. Yoshimatsu since this cultivar shows lower stylet growth at high temperatures (Noda \& Machado, 1992). This shows that progenies which can be obtained from this cultivar would show low abortion rate when compared to commercial cultivars.

Plant selection of this cultivar was efficient to obtain progeny P6 as the most productive, reaching $111 \mathrm{t} \mathrm{ha}^{-1}$ and average fruit mass of $142.5 \mathrm{~g}$; contrary to P7, which had the lowest performance, with $40.88 \mathrm{t} \mathrm{ha}^{-1}$ and $108.5 \mathrm{~g}$, respectively. The productivities of selected progenies were within the range which corresponds to commercial hybrids. As a consequence, selections using cv. Yoshimatsu would provide gains through so significant selections that their productivities would be similar to the commercial hybrids used in Rondônia.

\section{ACKNOWLEDGEMENTS}

To Foundation for research support of Amazonas (FAPEAM) for scientific initiation scholarship for the first author, to Federal Institute of Rondônia (IFRO) and to National Research Institute of the Amazon (INPA).

\section{REFERENCES}

ALVARES, CAA; STAPE, JL; SENTELHAS, PC; GONÇALVES, JLM; SPAROVEK, G. 2013. Keppen's climate classification map for Brazil. Meteorologische Zeitschrift 22: 711-728.

ANDRADE, JS; NINA, NVS; FIGUEIREDO, JNR. 2013. Caracterização físico-química do tomate (Solanum lycopersicum mill. Cv. 'Yoshimatsu') in natura e produção de tomate seco. In: NODA, H; SILVA, FILHO, DF; SOUZA, LAG. (eds). Agricultura familiar no Amazonas: conservação dos recursos ambientais. Manaus: NERUA/Instituto Nacional de Pesquisas da Amazônia. p.27-40.

BARRERO, LS; TANKSLEY, SD. 2004. Evaluating the genetic basis of multiplelocule fruit in a broad cross section of tomato cultivars. Theoretical and Applied Genetics 109: 669-679.

BORGUINI, RG. 2002. Tomate (Lycopersicon esculentum Mill.) orgânico: o conteúdo nutricional e a opinião do consumidor. 
Piracicaba: USP-ESALQ. 127p (M.Sc. thesis).

BORGUINI, RG; SILVA, MV. 2007. O conteúdo nutricional de tomates obtidos por cultivo orgânico e convencional. Revista Higiene Alimentar 45: 41-46.

CHENG, SS; CHU, EY. 2002. 'PARÁ BELO', um clone do tomateiro adaptado à Amazônia Oriental. Horticultura Brasileira 20: 516-519.

EMBRAPA. 2006. Sistema brasileiro de classificação de solos. Rio de Janeiro: Embrapa Solos. 286p.

FERREIRA, SMR; FREITAS, RJS; LAZZAR, EN. 2004. Padrão de qualidade e identidade do tomate (Lycopersicon esculentum Mill) de mesa. Ciência Rural 34: 329-335.

GUILHERME, DO; PINHO, L; COSTA, CA; ALMEIDA, AC; PAES, MCD; RODRIGUES, RJA; CAVALCANTI, TFM; FILHO, SCT; MENEZES, JBC; SALES, SS. 2008. Análise sensorial e físico-química em frutos de tomate cereja orgânicos. Horticultura Brasileira 26: 171-175.

IBGE - Instituto Brasileiro de Geografia e estatística. 2017. Available at ftp://ftp. ibge.gov.br/Estimativas_de_Populacao/ Estimativas_2017/estimativa_dou_2017.pdf. Accessed December 19, 2017.

JYOTHI, HK; SANTHOSHA, HM; BASAM, MA. 2012. Recent advances in breeding for bacterial wilt (Ralstonia solaneacearum) resistance in tomato. Current Biotica 6: 370-398.

LIPPMAN, Z; TANKSLEY, S. 2001. Dissecting the genetic pathway to extreme fruit size in tomato using a cross between the small fruited wild species Lycopersicon pimpinellifolium and $L$. esculentum var. Giant Heirloom. Genetics 158: 413-422.

LSPA - Levantamento Sistemático da Produção Agrícola. September 2017. Pesquisa mensal de previsão e acompanhamento das safras agrícolas no ano civil. Instituto Brasileiro de Geografia e Estatistica 30: 1-83.

MARTINS, LHP; NODA, H; MENDONÇA, MSP; MACHADO, FM. 2013. Tomate Yoshimatsu - uma cultivar adaptada ao trópico úmido brasileiro. In: NODA H; SILVA FILHO DF; SOUZA LAG. (eds). Agricultura familiar no Amazonas: conservação dos recursos ambientais. Manaus: NERUA/Instituto Nacional de Pesquisas da Amazônia. p. 15-26. MENEZES, D. 1998. Análise genética de um cruzamento dialélico em tomateiro (Lycopersicon esculentum Mill.). Recife: UFRPE. 95p (Ph.D. thesis)

MONTEIRO, CS; BALBI, ME; MIGUEL, OG; PENTEADO, PTPS; HARACEMIV, SMC. 2008. Qualidade nutricional e antioxidante do tomate "tipo italiano". Alimentos e Nutrição Araraquara 19: 25-31.

MORETTI, CL; SARGENT, SA; HUBER, DJ; CALBO, AG; PUSCHMANN, R. 1998. Chemical composition and physical properties of pericarp, locule and placental tissues of tomatoes with internal bruising. Journal of the American Society for Horticultural Science 123: 656-660.

NODA, H; MACHADO, FM. 1992. Avaliação de progênies de tomate (Lycopersicon esculentum) para cultivo sob temperaturas elevadas. Acta Amazônica 22: 183-190.

NODA, H; PAIVA, WO; SILVA FILHO, DF; MACHADO, FM. 1997. Melhoramento de hortaliças convencionais no trópico úmido brasileiro. In: NODA, H; SOUZA, LA; FONSECA, OJM (eds). Duas décadas de contribuição do INPA à pesquisa agronômica no trópico úmido. Manaus: INPA. p.60-87.

NODA, H. 2007. Melhoramento de hortaliças em climas desfavoráveis: o desafio do desenvolvimento de cultivares adaptadas à Amazônia. Melhoramento do tomateiro para o trópico úmido brasileiro. In: Congresso brasileiro de olericultura, 25. Resumos. Porto Seguro: SOB (CD-ROM).

PENA, MAA; NODA, H; MACHADO, FM; PAIVA, MSS. 2010. Adaptabilidade e estabilidade de genótipos de tomateiro sob cultivo em solos de terra firme e várzea da Amazônia infestados por Ralstonia solanacearum. Bragantia 69: 27-37.

RODRIGUES, MB; DORNELLES, ALC; OLIVEIRA, SAO; MORAES, MRJ; LISBOA, FJ; SILVA, DAG; PEREIRA, MB. 2008. Características físico-químicas de frutos de 25 cultivares de tomateiro tipo cereja. Horticultura Brasileira 26: 5463-5466.

SIDRA - Sistema IBGE de Recuperação Automática. Instituto brasileiro de geografia e estatistica. Available at https://sidra. ibge.gov.br/tabela/1612. Accessed September 9, 2017.

SILVA, FAZ; AZEVEDO, CAV. 2016. The assistat software version 7.7 and its use in the analysis of experimental data. African Journal of Agricultural Research 11: 3733-3740.

SOUSA, AA; GRIGIO, ML; NASCIMENTO, CR; SILVA, ACD; REGO, ER; REGO, MM. 2011. Caracterização química e física de frutos de diferentes acessos de tomateiro em casa de vegetação.Agro@mbiente On-line 5: 113-118.

STAT SOFT, INC. 2014. STATISTICA (data analysis software system), version 12 . Available at http://www.statsoft.com

TAIZ, L.; ZEIGER, E. 2004. Fisiologia vegetal. Porto Alegre: Artmed. 719p.

VILLAREAL, RL; MERCADO, FC; HSIUNG, LAI S0; LI, HU I. 1977. Fruit setting ability of heat tolerant, moisture - tolerant and traditional tomato cultivars grown under field and green house condition. Philippinne Journal of Crop Science 2: 55-61. 